\title{
The Paleomagnetism of Red Beds and Basalts of the Hettangian Extrusive Zone, Newark Basin, New Jersey
}

\author{
WIIIIAM K. WTTTE AND DENNIS V. KENT \\ Lamont-Doherty Geological Observatory and Department of Geological Sciences, Columbia University, \\ Palisades, New York
}

\begin{abstract}
A high unblocking temperature component of magnetization residing in hematite was isolated in 11 outcrop sites and 4 boreholes from Hettangian sedimentary rocks interbedded with the igneous extrusives of the Newark basin. This normal polarity characteristic magnetization has a mean direction (declination $=6.3^{\circ}$, inclination $=12.9^{\circ}$ after tilt correction) which is significantly shallower (by about $15^{\circ}$ ) than reported magnetization directions from the coeval basalts. Based on our demagnetization analysis of representative basalt samples, we attribute the difference between the sedimentary and basaltic directions to contamination of some of the basalt magnetizations by a steeper overprint An intermediate unblocking temperature magnetization recovered from the extrusive zone sedimentary rocks, consistent with evidence elsewhere in the Newark basin for a pervasive hydrothermal and remagnetization event at about $175 \mathrm{Ma}$, is a likely cause of the basalt contamination. The characteristic magnetization from the Hettangian sedimentary rocks yields a paleopole $\left(55.5^{\circ} \mathrm{N}, 94.6^{\circ} \mathrm{E}, d p=5.2^{\circ}, d m=5.4^{\circ}\right)$ which lies on the westbound, precusp portion of current paleomagnetic Euler pole apparent polar wander (APW) paths, in contrast with the Newark (and Hartford) basin basalt reference pole positions (such as the "Newark trend" N1 pole) which lie on the eastbound, postcusp portion of the APW path. A precusp pole position is more compatible with the relative age of the Hettangian extrusive zone pole with respect to the Sinemurian/Pliensbachian poles which define the cusp but implies large changes in the rate of APW in the Late Triassic and Early Jurassic.
\end{abstract}

\section{INTRODUCTION}

Paleomagnetic poles from the Mesozoic igneous rocks of eastern North America (the "Newark trend" of Smith and Noltimier [1979]) have provided important constraints for the Mesozoic apparent polar wander (APW) path of North America. For example, in their 30 m.y. moving time window method of constructing an APW path, Irving and Irving [1982] used data from nine separate studies of these igneous rocks which were assigned ages ranging from 204 to $170 \mathrm{Ma}$; these results constitute up to $75 \%$ of the reference poles used in calculating the $10 \mathrm{~m} . y$. interval mean paleopoles from $210 \mathrm{Ma}$ to $160 \mathrm{Ma}$. More recent APW path syntheses [Gordon et al., 1984; May and Butler, 1986] have used the N1 and N2 reference poles, derived from a compilation of results from the Newark trend igneous rocks [Smith and Noltimier, 1979], as key constraints for the Early and Middle Jurassic. N1, assigned an age of 195 Ma by Gordon et al. [1984] using new decay constants, was derived from 72 site-mean virtual geomagnetic poles (VGPs) from lava flows of the Newark and Hartford basins and selected igneous intrusions of the Hartford basin; N2, assigned an age of $179 \mathrm{Ma}$, was based on 155 site-mean VGPs from dikes and sills from Maryland to Connecticut and one site in Nova Scotia.

Recent ${ }^{40} \mathrm{Ar} /{ }^{39} \mathrm{Ar}$ age spectra studies of the diabase sheets and associated rocks of the early Mesozoic rift basins of eastem North America [Sutter, 1988] indicate that many of the igneous intrusions which yield $\sim 179 \mathrm{Ma}$ radiometric dates actually crystallized at about the time of Newark Supergroup basalt extrusion $(\sim 200 \mathrm{Ma})$ and were later reset by a widespread hydrothermal event at $\sim 175 \mathrm{Ma}$. Supporting evidence comes from field and geochemical observations in the Hartford basin

Copyright 1990 by the American Geophysical Union.
[Philpotts and Martello, 1986] which show that the Talcott, Holyoke, and Hampden Basalts (included in the N1 pole compilation) were fed by the Fairhaven, Buttress, and Bridgeport dikes (included in the N2 pole compilation). In the Newark basin, detailed field, borehole, and geophysical observations indicate that an extension of the Palisade Sill actually fed some of the basalt flows of the Newark basin [Kodama, 1983; Ratcliffe, 1988]. Together these findings suggest that the areally extensive Newark Supergroup igneous extrusive and associated intrusive rocks are in fact of similar age instead of spanning the 20 to 35 m.y. attributed to them by the APW path syntheses. Olsen and Fedosh [1988] (see also Olsen et al. [1989]) have shown that the bulk of this igneous activity was probably confined to less than $0.7 \mathrm{~m}$.y. in the biostratigraphically determined early Hettangian, the lowest stage of the Jurassic.

If the bulk of the Newark trend igneous rocks crystallized at $\sim 200 \mathrm{Ma}$, then the N1 and N2 magnetizations cannot both (if either) represent primary thermoremanent magnetizations. Witte and Kent [1989] found a close similarity in direction in a common reference frame (geographic or tilt corrected) of the N2 magnetization and the pervasive overprint magnetization observed in Upper Triassic (Camian and Norian) sedimentary rocks of the Newark basin; this correspondence suggested that the N2 magnetization is almost entirely secondary, most probably acquired after folding and tilting at $\sim 175 \mathrm{Ma}$. We now consider the problem of determining whether the magnetizations that contribute to the $\mathrm{N} 1$ pole from the Newark basin are primary. Circumstantial evidence suggesting that the $\mathrm{N} 1$ magnetizations might be at least in part secondary include the wide range of K-Ar ages obtained for the Hartford and Newark basin flows (171 to $279 \mathrm{Ma}$ in the work by Seidemann et al. [1984]), the existence of economically significant copper-prehnite-zeolite mineralization due to large-scale hydrothermal alteration within the Newark basin extrusive zone [Cummings, 1988; Schaller, 1932], and the observation (discussed later) that the N1 pole is out of spatiotemporal 
sequence with respect to reference poles from younger early Jurassic rocks from elsewhere in North America.

To test the reliability of the N1 magnetization, we sampled the sedimentary rocks which are intercalated with the basaltic lava flows in the Newark basin. Opdyke [1961] previously found similar magnetization directions in sedimentary rocks without magnetic cleaning and igneous rocks with magnetic cleaning from the Newark basin. On the other hand, McIntosh et al. [1985] concluded that the natural remanent magnetization (NRM) of the Newark basin sedimentary rocks, including five sites sampled in the extrusive zone, contains large unresolved secondary magnetizations of Mesozoic and Cenozoic age after blanket thermal demagnetization. However, we showed that two components of magnetization can be effectively isolated with complete step wise thermal demagnetization in our study of the oldest (Camian and Norian) sedimentary rocks from the Newark basin: a normal polarity overprint of probable Middle Jurassic age and an early formed characteristic magnetization [Witte and Kent, 1989]. This suggests that the lithologically similar sedimentary rocks of the Hettangian extrusive zone might likewise provide reliable data for comparison with the $\mathrm{N} 1$ magnetizations as represented in the Newark basin basalts.

\section{GEOLOGIC SETTING AND SAMPLING}

The Hettangian extrusive zone rocks of the Newark basin [Olsen, 1980] consist of two 200 to 300-m-thick sedimentary formations (Feltville and Towaco) interbedded with three lava flow units (the Orange Mountain, Preakness and Hook Mountain basalts, which are often informally termed the "Watchung basalts") and are best exposed in the northeastern Newark basin with maximum bedding dips of about $30^{\circ}$ (Figure 1). Van Fossen et al. [1986] suggested the possibility of complex tectonic rotations along the border fault of the Newark basin (see also Kodama [1987]; Van Fossen et al. [1987]), hence we avoided sampling in the region of suspected cryptic strain on the western limb of the Watchung syncline.

At least six samples (spanning about 3 to $35 \mathrm{~m}$ stratigraphically) were taken at each of 13 outcrop sites distributed through the Feltville and Towaco Formations and from a thin $(\sim 10 \mathrm{~m})$ sedimentary interbed within the Preakness Basalt (Table 1, Figures 1 and 2). The sedimentary rocks sampled for this study consist of fine- to medium-grained, reddish to tan sandstones and mudstones deposited in lacustrine and fluvial environments that occupied the topographic

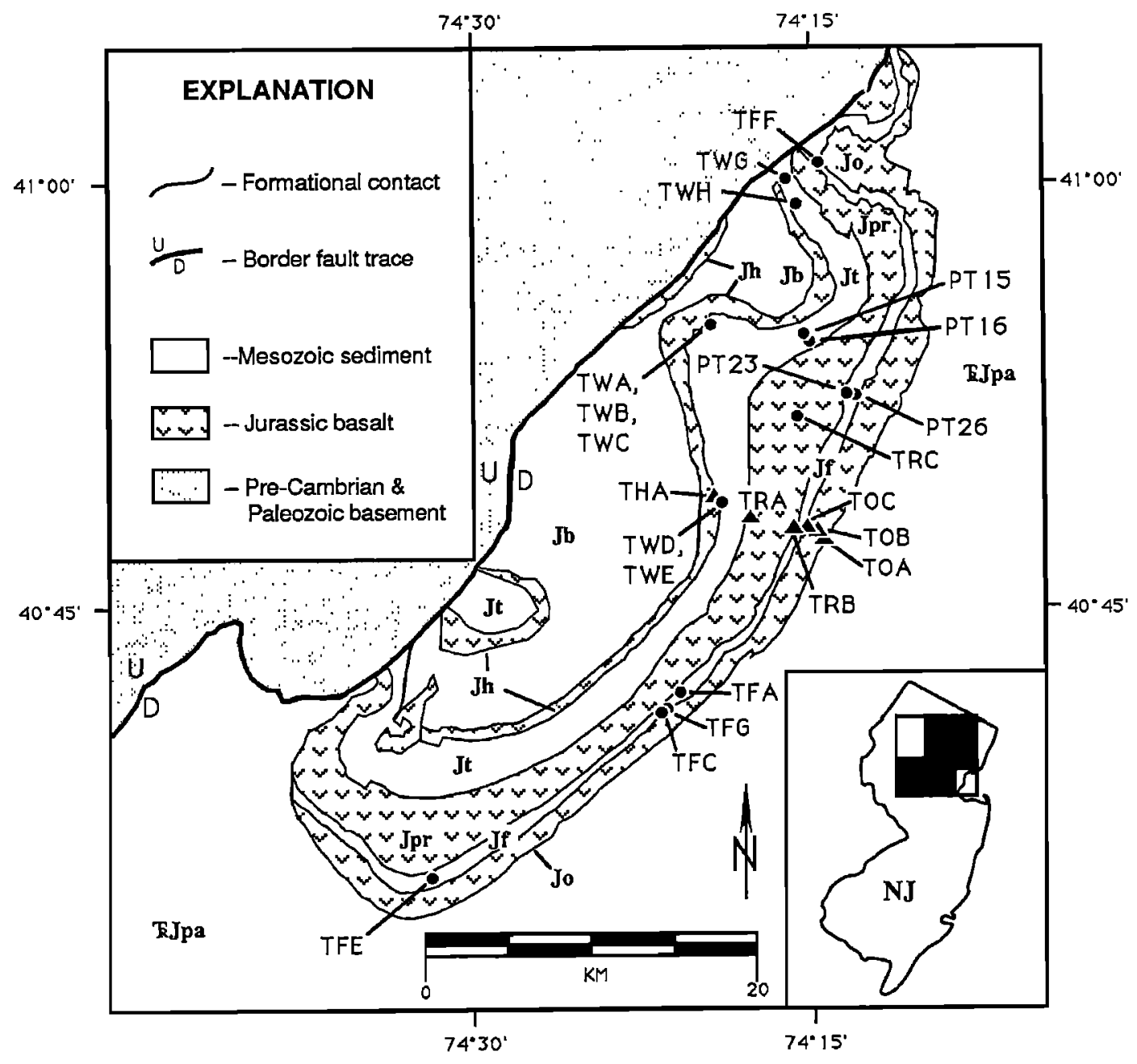

Fig. 1. Location map of Newark extrusive zone sedimentary (circles) and basaltic (triangles) sampling sites (Tables 1 and 2). The sedimentary formations are indicated as TRJpa - Passaic Formation, Jf - Feltville Formation, Jt - Towaco Formation, $\mathrm{Jb}$ - Boonton Formation. The igneous formations are indicated as Jo - Orange Mountain Basalt, Jpr - Preakness Basalt, Jh Hook Mountain Basalt. Site TRC was taken in a sedimentary interbed of the Preakness Basalt. Base map from Olsen et al. [1989]. 
TABLE 1. Site Locations and Structural Attitudes

\begin{tabular}{|c|c|c|c|c|}
\hline$\overline{\text { Site }}$ & Longitude (W) & Latitude $(\mathbb{N})$ & Strike & Dip \\
\hline \multicolumn{5}{|c|}{ Sedimentary Outcrops } \\
\hline TFA & $\begin{array}{l}74^{\circ} 21.81^{\prime} \\
74^{\circ} 230^{\prime}\end{array}$ & & $240^{\circ}$ & $12 \mathrm{~N}$ \\
\hline TFC & $\begin{array}{l}74^{\circ} 23.00^{\prime} \\
74^{\circ} 32.08^{\prime}\end{array}$ & $\begin{array}{l}40^{\circ} 40.84 \\
40^{\circ} 36.16^{\prime}\end{array}$ & $\begin{array}{l}237^{\circ} \\
243^{\circ}\end{array}$ & $\begin{array}{l}150 \mathrm{~N} \\
00 \mathrm{~N}\end{array}$ \\
\hline TFF & $74^{\circ} 15.34^{\prime}$ & $41^{\circ} 00.67$ & $147^{\circ}$ & $\begin{array}{l}90 \mathrm{~N} \\
250 \mathrm{~W}\end{array}$ \\
\hline IFF & $74^{\circ} 22.80^{\prime}$ & $40^{\circ} 40.95^{\prime}$ & $237^{\circ}$ & $\begin{array}{l}-5 \mathrm{~W} \\
15 \mathrm{~N}\end{array}$ \\
\hline TRC & $74^{\circ} 15.93^{\prime}$ & $40^{\circ} 51.87^{\prime}$ & $197^{\circ}$ & $15^{\circ} \mathrm{W}$ \\
\hline TWA & $74^{\circ} 19.76^{\prime}$ & $40^{\circ} 55.17^{\prime}$ & $238^{\circ}$ & $60 \mathrm{~N}$ \\
\hline TWB & $74^{\circ} 19.76^{\prime}$ & $40^{\circ} 55.17$ & $238^{\circ}$ & $6 \mathrm{~N}$ \\
\hline TWC & $74^{\circ} 19.76^{\prime}$ & $40^{\circ} 55.17^{\prime}$ & $238^{\circ}$ & $6 \mathrm{~N}$ \\
\hline TWD & $74^{\circ} 19.58^{\prime}$ & $40^{\circ} 48.93^{\prime}$ & $176^{\circ}$ & $10^{\circ} \mathrm{W}$ \\
\hline TWE & $74^{\circ} 19.58^{\prime}$ & $40^{\circ} 48.93^{\prime}$ & $171^{\circ}$ & $16^{\circ} \mathrm{W}$ \\
\hline TWG & $74^{\circ} 16.42^{\prime}$ & $40^{\circ} 59.82^{\prime}$ & $147^{\circ}$ & $20^{\circ} \mathrm{W}$ \\
\hline TWH & $74^{\circ} 16.14^{\prime}$ & $40^{\circ} 59.43^{\prime}$ & $162^{\circ}$ & $15^{\circ} \mathrm{W}$ \\
\hline \multicolumn{5}{|c|}{$A C E$ Boreholes } \\
\hline PT15 & $74^{\circ} 14.96^{\prime}$ & $40^{\circ} 54.73^{\prime}$ & $215^{\circ}$ & $10^{\circ}-17^{\circ *}$ \\
\hline PT16 & $74^{\circ} 14.87^{\prime}$ & $40^{\circ} 54.52$ & $220^{\circ}$ & $8^{\circ}-12^{\circ *}$ \\
\hline PT23 & $74^{\circ} 13.67^{\prime}$ & $40^{\circ} 52.82^{\prime}$ & $205^{\circ}$ & $7^{0}-15^{\circ *}$ \\
\hline PT26 & $74^{\circ} 13.44^{\prime}$ & $40^{\circ} 52.71$ & $205^{\circ}$ & $0^{\circ}-10^{\circ *}$ \\
\hline \multicolumn{5}{|c|}{ Extrusive Zone Basalts } \\
\hline TOA & $74^{\circ} 14.92^{\prime}$ & $40^{\circ} 47.44^{\prime}$ & $205^{\circ}$ & $15^{\circ} \mathrm{W}+$ \\
\hline TOB & $74^{\circ} 15.05^{\prime}$ & $40^{\circ} 47.83^{\prime}$ & $205^{\circ}$ & $15^{\circ} \mathrm{Wt}$ \\
\hline TOC & $74^{\circ} 15.40^{\prime}$ & $40^{\circ} 47.88^{\prime}$ & $205^{\circ}$ & $15^{\circ} \mathrm{Wt}$ \\
\hline TRA & $74^{\circ} 17.16^{\prime}$ & $40^{\circ} 48.31^{\prime}$ & $190^{\circ}$ & $15^{\circ} \mathrm{Wt}$ \\
\hline TRB & $74^{\circ} 16.32^{\prime}$ & $40^{\circ} 47.90^{\prime}$ & $205^{\circ}$ & $15^{\circ} \mathrm{W} \dagger$ \\
\hline THA & $74^{\circ} 19.79^{\prime}$ & $40^{\circ} 49.07^{\prime}$ & $182^{\circ}$ & $6^{\circ} \mathrm{W}^{+}$ \\
\hline
\end{tabular}

* Strike and dip direction extrapolated from the local outcrop pattem [Lytlle and Epstein, 1987]; dip angle was determined from examination of the vertical core.

† Structural correction extrapolated from the local outcrop pattem [Lyttle and Epstein, 1987] and the bedding attitudes of enclosing sedimentary rocks.

Newark basin. McIntosh et al. [1985] found that microcrystalline hematite is the predominant oxide mineral in the sediments, with races of specular hematite and altered ilmenite. Neither magnetite nor titanomagnetite were seen.

The lower parts of the interbedded sedimentary formations are not well exposed, but we obtained samples from four boreholes drilled by the Army Corp of Engineers (ACE) in the northeastem Newark basin [Fedosh and Smoot, 1988] to obtain more complete stratigraphic coverage (Table 1, Figures 1 and 2). The ACE cores were not azimuthally oriented during drilling; however, because the cores were drilled vertically into regionally homoclinal beds it was possible to reconstruct the orientation of the cores relative to present geographic coordinates by assigning to the strike of the bedding observed in the cores the strike direction projected from the surface. The measured magnetization directions could also then be tilt corrected by rotating the vectors about the strike line until the bedding was horizontal. For samples from nine levels from the four ACE cores, the observed bedding dip was too shallow $\left(<10^{\circ}\right)$ to obtain a reliable estimate of bedding strike, and these samples yield only inclination data. Samples were taken from ACE cores PT23 and PT26 in the Feltville Formation and PT15 and PT16 in the Towaco Formation. Paired specimens were taken from stratigraphic levels spaced at $\sim 10-\mathrm{m}$ intervals within the cores, with a total of 6 to 11 levels sampled from each borehole.

Finally, a representative set of samples was taken from the basalt flows. The Orange Mountain Basalt was sampled at three sites (bottom, middle, and top) at roadcuts along interstate highway 280 (I-280) and samples from two sites at the top and the bottom of the Preakness Basalt were taken along I-280 as well. In the Hook Mountain Basalt, the third and topmost igneous formation of the Newark basin extrusive zone, we took samples from one site near the basal contact of the basalt with the underlying Towaco Formation (Table 1, Figures 1 and 2). Each of our sites sampled a different cooling unit of the 11 recognized in the Newark extrusive zone [Fedosh and Smoot, 1988].

\section{Paleomagnetic Results}

\section{Sedimentary Rocks in Outcrop}

NRM intensities of the redbed samples varied from 1 to 100 $\mathrm{mA} / \mathrm{m}$. Progressive altemating field (AF) and thermal demagnetizations of the sedimentary rocks were performed. Thermal demagnetization proved the more useful in resolving components of magnetization because of high coercivities associated with the hematite carrier of remanence. Each sample was thermally demagnetized at a minimum of 12 temperature steps. Magnetization component directions were estimated by the principal component analysis (PCA) method [Kirschvink, 1980] and mean directions calculated using standard $F$ isher [1953] statistics.

At demagnetization temperatures above $300^{\circ} \mathrm{C}$, after the removal of spurious magnetizations, two components of magnetization were commonly but not invariably resolved. Most readily isolated was the final, high unblocking temperature magnetization we refer to as the $C$ component. It has shallow, northerly directions and was generally unblocked above $660^{\circ} \mathrm{C}$, thus clearly residing in hematite (Figures $3 a$ and $3 b$ ). Site mean directions for this component were calculated for 11 of the 13 sites sampled which displayed a clearly defined C component trajectory in at least three samples per site (Table 2). Samples from two sites, TWA and TFF (both gray sandstones), failed to exhibit linear trajectories above $660^{\circ} \mathrm{C}$ and were excluded from the $\mathrm{C}$ component mean. Although the mean direction at site TWG is poorly constrained (Table 2), the distribution of directions is statistically nonrandom [Irving. 1964] with a mean similar to the other sites, thus we see no reason to exclude it from the overall mean. The overall mean $C$ component direction before tilt correction is (declination/inclination) $008.8^{\circ} / 15.1^{\circ}, \alpha_{95}=6.4^{\circ}$ and after tilt correction is $006.3^{\circ} / 12.9^{\circ}, \alpha_{95}=6.0^{\circ}$ (Figure $3 d$ ); due to the lack of sufficient bedding orientation variability, a fold test is not statistically conclusive.

In the intermediate demagnetization temperature range of $300^{\circ} \mathrm{C}$ to about $620^{\circ} \mathrm{C}$, another component of magnetization (B) could sometimes be isolated (Figure $3 b$ ). This component was always directed to the north and down with an inclination somewhat steeper than the $C$ component, but shallower than the present-day field. The B component was identified as a demagnetization trajectory distinct from the high-temperature C component in at least three samples from each of four sites, with a mean direction of $004.3^{\circ} / 35.6^{\circ}, \alpha_{95}=8.8^{\circ}(N=4$ sites $)$ in geographic, and $358.7^{\circ} / 26.4^{\circ}, \alpha_{95}=10.1^{\circ}$ in bedding coordinates (Table 2, Figure $3 e$ ). In the nine remaining sites, the $\mathrm{B}$ and $\mathrm{C}$ component demagnetization trajectories were less obviously separated; the uniform normal polarity of the $C$ component and near collinearity of the $B$ and $C$ components combine to complicate an unambiguous isolation of the $B$ component direction. However, if we include the directions estimated by the PCA method for magnetizations unblocked between $300^{\circ}$ and $620^{\circ} \mathrm{C}$ in those nine sites, the overall mean 


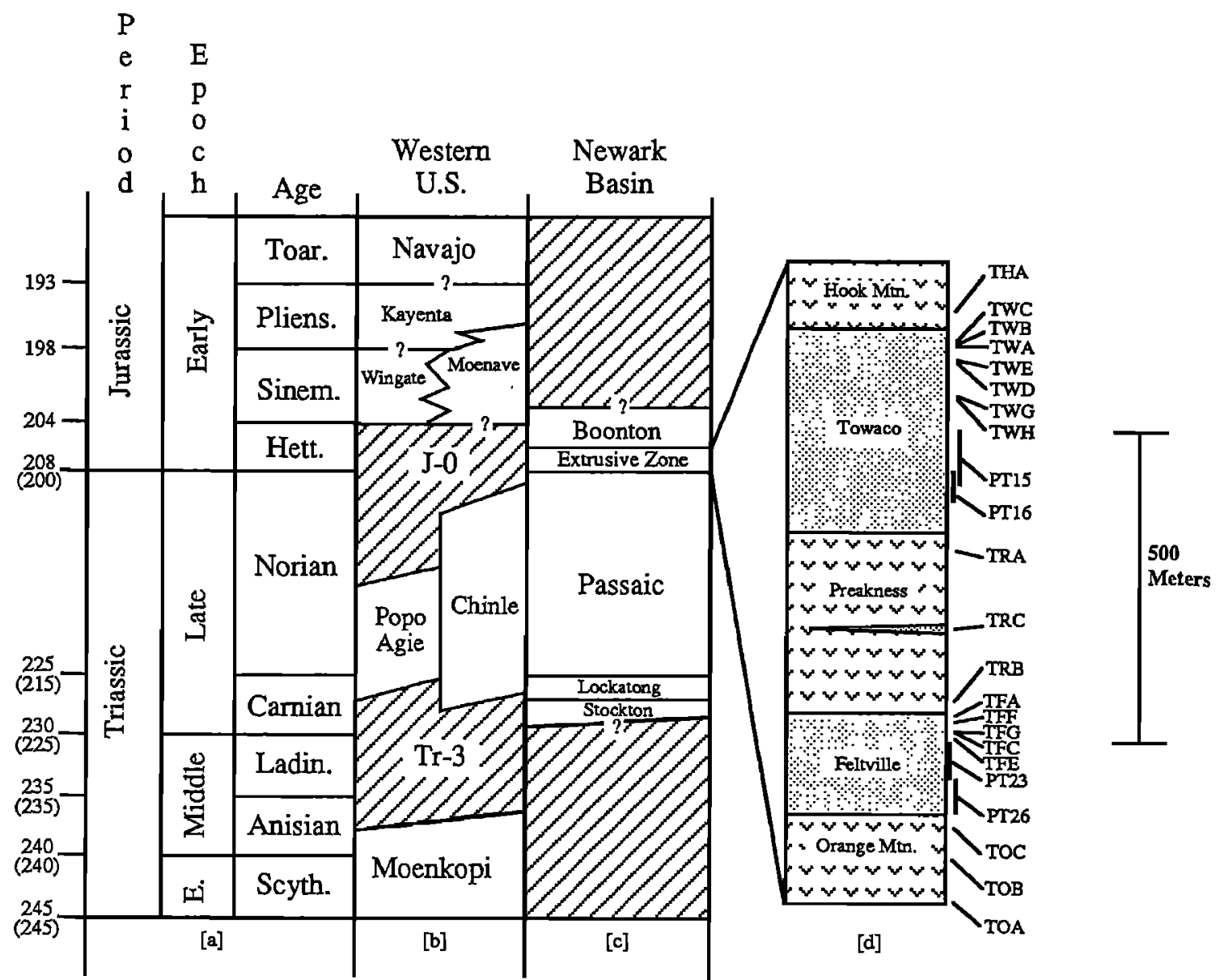

Fig. 2. Temporal correlation (Column $a$ after Palmer [1983], with Triassic time scale after Webb [1981] in parentheses) between Upper Triassic and Lower Jurassic formations of the American southwest (Column $b$ after Pipiringos and O'Sullivan [1978]; Imlay [1980]) and the Newark basin (Column $c$ after Comet and Olsen [1985]). Column $d$ shows the stratigraphic distribution of sampling sites within the Newark basin extrusive zone.

B component direction (combining data from the sites with articulated demagnetization trajectories with the other nine sites yielding $N=13$ sites) becomes $005.0^{\circ} / 28.9^{\circ}, \alpha_{95}=8.4^{\circ}$ in geographic coordinates and $359.5^{\circ} / 26.1^{\circ}, \alpha_{95}=9.5^{\circ}$ after structural correction (Table 2, Figure $3 e$ ). In either case, the $\mathrm{B}$ and $C$ components are significantly different in a common (geographic or tilt corrected) reference frame.

\section{Sedimentary Rocks in the Subsurface}

A pattern of multicomponent magnetizations similar to that in the outcrop samples was observed in thermal demagnetization experiments on samples from the ACE cores (Figure 3c). The natural remanent magnetization consisted of a shallow magnetization unblocked at high temperatures (above $620^{\circ} \mathrm{C}$ ) and, in many samples, a somewhat steeper magnetization (but shallower than the present field) resolved at intermediate temperatures $\left(-300^{\circ} \mathrm{C}\right.$ to $\left.\sim 620^{\circ} \mathrm{C}\right)$. In all cases the high and intermediate unblocking temperature magnetization components are of the same polarity. Although the indirect method employed to orient the samples from the ACE boreholes results in considerable scatter in the declinations of the high and intermediate unblocking temperature magnetizations (Figures $3 f$ and $3 g$ ), it is demonstrably adequate to determine the polarity of both magnetizations as normal. The scatter and apparent bias toward the northwest in the declinations of both the high and intermediate temperature components may be due to structure more complicated than assumed between the surface and subsurface, as well as crossbedding in the fluvial and deltaic parts of the ACE sections. Thus we consider only the mean inclination directions in comparing the ACE magnetizations with those from the outcrop sampling sites. Using the statistical method of McFadden and Reid [1982], unbiased mean inclinations and $\alpha_{95}$ confidence intervals were determined for the magnetization components in geographic and tilt-corrected coordinates.

The high-temperature component recovered from the ACE cores is very similar in its demagnetization characteristics to the $\mathbf{C}$ component isolated in the outcrop samples; the mean inclination in geographic coordinates is $20.9^{\circ}$ (with a $95 \%$ confidence interval of $14.6^{\circ}$ to $28.2^{\circ}$ for 19 sample levels); after bedding tilt-correction it becomes $11.3^{\circ}$ (95\% confidence interval $=5.0^{\circ}$ to $18.7^{\circ}$ ), which compares well with the mean tilt corrected inclination of $12.9^{\circ} \pm 4.7^{\circ}$ (with a $95 \%$ confidence interval for inclination calculated by the method of Demarest [1983]) obtained for the high-temperature C component from the fully oriented surface sites (Figure $3 f$ ). Likewise, the intermediate unblocking temperature component in the ACE cores is probably the same overprint recovered from the surface samples. The mean inclination in geographic coordinates determined from the ACE borehole samples is $31.7^{\circ}$ (with a $95 \%$ confidence interval of $27.6^{\circ}$ to $36.8^{\circ}$ for 23 

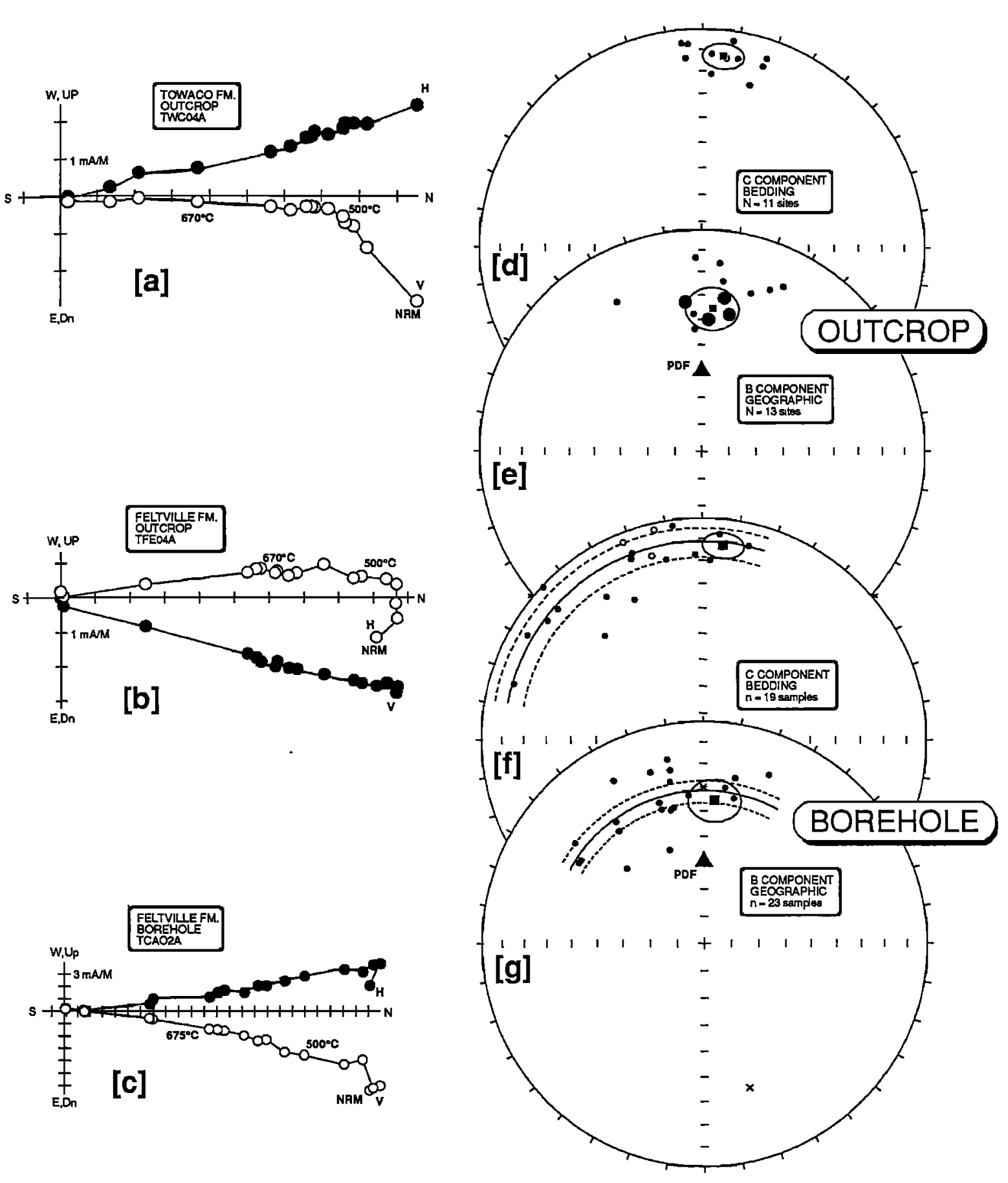

Fig. 3. Paleomagnetic results from Newark extrusive zone sedimentary rocks. Zijderveld [1967] demagnetograms of progressive thermal demagnetization of NRM, with open (solid) symbols projected on the vertical (horizontal) axes: (a) outcrop sample from the Towaco Formation, (b) outcrop sample from the Feltville Formation, and (c) sample from the Feltville Formation in ACE borehole PT26. Equal area stereographic projections of results from outcrop: (d) high unblocking temperature or $C$ component outcrop site mean directions after tilt correction (circles, all on lower hemisphere), with mean direction (square) and $\alpha_{95}$ (ellipse); (e) intermediate unblocking temperature or B component site mean directions before tilt correction (circles, all on lower hemisphere), with the mean (square) and $\alpha_{95}$ (ellipse) of the four sites (larger circles) with well-defined B component demagnetization trajectories, and the dipole field direction (triangle). Equal area stereographic projections of borehole results: $(f) C$ component sample directions (open circles on upper hemisphere, solid circles on lower hemisphere) from the four borehole sites after tilt correction, with their mean inclination (solid arc) and its $95 \%$ confidence limits (dashed arcs) compared to the $C$ component outcrop mean direction (square) and its $\alpha_{95}$ (ellipse); (g) B component sample directions (circles, with two samples rejected due to atypically low unblocking temperatures indicated by crosses) from the borehole sites before tilt correction, with their mean inclination (solid arc) and its $95 \%$ confidence limits (dashed arcs) compared to the B component outcrop mean direction (square) and its $\alpha_{95}$ (ellipse). 
TABLE 2. Site Mean Component Directions from extrusive zone sedimentary rocks

\begin{tabular}{|c|c|c|c|c|c|c|c|c|c|c|c|c|c|c|}
\hline \multirow[b]{2}{*}{ Site } & \multirow{2}{*}{\multicolumn{7}{|c|}{ CComponent }} & \multicolumn{7}{|c|}{ B Cornoonent } \\
\hline & & & $\alpha_{95}$ & GDec & Glnc & BDec & BInc: & $\mathbf{n}$ & $\mathbf{k}$ & $\alpha_{95}$ & GDec & GInc & BDec & BInc \\
\hline $\begin{array}{l}\text { TFA } \\
\text { TFC } \\
\text { TFE } \\
\text { TFF } \\
\text { TFG } \\
\text { TRC } \\
\text { TWA } \\
\text { TWB } \\
\text { TWC } \\
\text { TWD } \\
\text { TWE } \\
\text { TWG } \\
\text { TWH }\end{array}$ & $\begin{array}{r}7 / 11 \\
4 / 5 \\
6 / 8 \\
0 / 3 \\
6 / 7 \\
5 / 5 \\
0 / 5 \\
5 / 5 \\
4 / 5 \\
4 / 5 \\
4 / 5 \\
3 / 6 \\
5 / 5\end{array}$ & $\begin{array}{r}104 \\
56 \\
12 \\
- \\
36 \\
43 \\
- \\
102 \\
39 \\
147 \\
77 \\
10 \\
46\end{array}$ & $\begin{array}{r}5.9 \\
12.4 \\
20.5 \\
\overline{11.4} \\
11.8 \\
\overline{7} .6 \\
14.9 \\
7.6 \\
10.5 \\
40.2 \\
11.5\end{array}$ & $\begin{array}{c}020.9 \\
357.6 \\
012.3 \\
\overline{357.5} \\
010.1 \\
\overline{-} \\
020.0 \\
354.6 \\
009.5 \\
021.1 \\
007.3 \\
005.0\end{array}$ & $\begin{array}{c}21.4 \\
20.3 \\
20.1 \\
\overline{27.1} \\
7.0 \\
\overline{13.8} \\
12.2 \\
11.4 \\
16.1 \\
8.9 \\
6.3\end{array}$ & $\begin{array}{c}018.0 \\
355.8 \\
010.6 \\
\overline{3} \\
354.8 \\
008.5 \\
- \\
019.0 \\
354.2 \\
007.3 \\
016.0 \\
003.0 \\
002.8\end{array}$ & $\begin{array}{c}\text { Outcr } \\
13.6 \\
7.3 \\
13.0 \\
\overline{14.0} \\
5.1 \\
\overline{0} \\
10.0 \\
6.8 \\
13.6 \\
23.5 \\
21.4 \\
11.9\end{array}$ & $\begin{array}{l}o p \\
7 / 11 \\
* 4 / 5 \\
* 8 / 8 \\
3 / 3 \\
* 7 / 7 \\
* 5 / 5 \\
5 / 5 \\
5 / 5 \\
5 / 5 \\
5 / 5 \\
4 / 5 \\
3 / 6 \\
5 / 5\end{array}$ & $\begin{array}{r}119 \\
604 \\
24 \\
10 \\
79 \\
156 \\
54 \\
15 \\
18 \\
20 \\
45 \\
11 \\
20\end{array}$ & $\begin{array}{r}5.6 \\
3.7 \\
11.5 \\
42.2 \\
6.8 \\
6.2 \\
10.5 \\
20.2 \\
18.5 \\
17.7 \\
13.9 \\
38.3 \\
17.6\end{array}$ & $\begin{array}{l}022.7 \\
353.7 \\
008.7 \\
330.4 \\
003.1 \\
011.8 \\
357.1 \\
027.2 \\
358.5 \\
007.3 \\
017.3 \\
356.6 \\
005.6\end{array}$ & $\begin{array}{l}21.9 \\
33.1 \\
30.8 \\
23.7 \\
40.2 \\
37.4 \\
43.8 \\
18.4 \\
13.7 \\
23.6 \\
26.3 \\
37.8 \\
15.9\end{array}$ & $\begin{array}{l}019.7 \\
350.5 \\
006.1 \\
319.5 \\
357.6 \\
001.0 \\
354.6 \\
025.7 \\
358.0 \\
002.8 \\
009.0 \\
339.9 \\
000.9\end{array}$ & $\begin{array}{r}14.4 \\
19.5 \\
23.4 \\
22.7 \\
27.7 \\
34.7 \\
38.5 \\
15.2 \\
8.5 \\
25.2 \\
32.4 \\
45.1 \\
21.3\end{array}$ \\
\hline $\begin{array}{l}\text { Geo } \\
\text { Bed }\end{array}$ & $\begin{array}{l}1 / 13 \\
1 / 13\end{array}$ & $\begin{array}{l}52 \\
59\end{array}$ & $\begin{array}{l}6.4 \\
6.0\end{array}$ & $\begin{array}{c}008.8 \\
--\end{array}$ & $\begin{array}{c}15.1 \\
-\end{array}$ & $\overline{-}^{O 06.3}$ & $\begin{array}{c}\text { Acrop } 1 \\
\overline{12.9}\end{array}$ & $\begin{array}{l}\text { Aeans } \\
4 / 13 \\
4 / 13\end{array}$ & $\begin{array}{r}109 \\
84\end{array}$ & $\begin{array}{r}8.8 \\
10.1\end{array}$ & $\begin{array}{c}004.3 \\
-\end{array}$ & $\begin{array}{c}35.6 \\
-\end{array}$ & $35 \overline{8.7}$ & $\overline{26.4}$ \\
\hline $\begin{array}{l}\text { Geo } \\
\text { Bed }\end{array}$ & $\begin{array}{l}19 \\
19\end{array}$ & $\begin{array}{r}(14 . \\
5 .\end{array}$ & $\begin{array}{l}5 \\
-2 \\
-18\end{array}$ & $\begin{array}{l}\text { Mean I } \\
2) \dagger- \\
\text { D) } \dagger-\end{array}$ & $\begin{array}{c}\text { nclinati } \\
20.9 \\
-\end{array}$ & $\begin{array}{c}\text { ons in } B C \\
- \\
-\end{array}$ & $\begin{array}{c}\text { ohehole } \\
\overline{11.3}\end{array}$ & $\begin{array}{c}P T 15 \\
23 \\
23\end{array}$ & $\begin{array}{r}5, P T) \\
(27.6 \\
(21.2\end{array}$ & $\begin{array}{l}16, P T \\
6-36.8 \\
2-30.3\end{array}$ & $\begin{array}{l}23, \text { PT26 } \\
\text { †ो -- } \\
\dagger \dagger-\end{array}$ & $\begin{array}{c}31.7 \\
-\end{array}$ & - & $\overline{25.4}$ \\
\hline
\end{tabular}

The column $n$ represents the number of independently oriented specimens with linear B or C component trajectories (for means, number of selected sites)/number of independently oriented specimens demagnetized (for means, number of sites sampled), $k$ is precision parameter, $\alpha_{95}$ is radius of $95 \%$ cone of confidence of mean direction in degrees, GDec and GInc are the magnetization declination and inclination (in degrees) before tilt correction, BDec and BInc are the magnetization declination and inclination (in degrees) after tilt correction.

* Sites within which $\mathrm{B}$ and $\mathrm{C}$ component demagnetization trajectories were highly ariculated and used for overall B component mean direction.

$\dagger$ Numbers in parentheses are the $95 \%$ confidence intervals on the mean inclination estimate for boreholes.

sample levels), similar to the mean inclination in geographic coordinates, $35.6^{\circ} \pm 7.0^{\circ}$, obtained for the intermediate temperature B component from four outcrop sites (Figure $3 g$ ).

\section{Interpretation of Results From Extrusive Zone Sedimentary Rocks}

The intermediate unblocking temperature B component isolated in the Hettangian sedimentary outcrop sites $\left(004.3^{\circ} 35.6^{\circ}, \alpha_{95}=8.8^{\circ}, N=4\right)$ is not as well defined as the more robust overprint magnetization we previously described in Upper Triassic (Carnian/Norian) sedimentary rocks (upper Stockton, Lockatong, and lower Passaic formations) of the Newark basin $\left(005.0^{\circ} / 40.4^{\circ}, \alpha_{95}=3.8^{\circ}, N=22\right.$; Witte and Kent [1989]); but nonetheless the two are very similar to each other in their demagnetization properties, consistent normal polarity, and direction. A secondary origin for the intermediate unblocking temperature magnetization observed in Newark basin sedimentary rocks of widely varying age is further demonstrated by a negative local fold test in the Jacksonwald syncline on the upper Passaic Formation which immediately underlies the extrusive zone [Witte et al., 1989]. This result also implies that the intermediate unblocking temperature component of magnetization is best considered in the geographic frame of reference, i.e., acquired after folding and tilting of the Newark basin strata. The mean B component direction in the Hettangian sediments, however, does not correspond to the present-day field, and the general agreement in $\mathbf{B}$ component magnetization directions between the subsurface and surface lends support to the interpretation of the B component magnetization as a pervasive overprint of ancient origin, rather than the result of recent surficial weathering processes.

In a common (tilt corrected) reference frame, the mean $C$ component direction from the extrusive zone outcrop sedimentary rocks $\left(006.3^{\circ} / 12.9^{\circ}, \alpha_{95}=6.0^{\circ}\right)$ is significantly different from the direction reported by McIntosh et al. [1985] from the coeval Watchung basalts $\left(007.7^{\circ} / 28.4^{\circ}, \alpha_{95}=6.2, N\right.$ $=18$ sites). The difference is predominantly in inclination, the sedimentary $C$ component being some $15^{\circ}$ shallower than the basalt magnetization. Diagnostic reversal or fold tests are not possible for either the uniformly normal polarity basalts or sedimentary rocks in the northeastern Newark basin, and hence constraints on the degree of contamination or the age of either magnetization must be argued from more indirect evidence.

We have obtained a positive fold test on the high unblocking temperature magnetization from the upper Passaic Formation which immediately underlies the extrusive zone in the Jacksonwald syncline [Witte et al., 1989]; from the similar demagnetization behavior exhibited by the $\mathrm{C}$ component in the extrusive zone, we infer that this component was also acquired early in these lithologically similar rocks. The shallower mean inclination of the $C$ component of magnetization in the extrusive zone sediments, relative to the basalt mean inclination of McIntosh et al. [1985], might be attributed to a sedimentary inclination shallowing process. For example, if the depositional or compaction process follows the classical relationship: $\tan I_{o}=f \cdot \tan I_{f}[K i n g$, 1955; Anson and Kodama, 1987], and the basalt magnetization can be taken as representative of the field inclination $\left(I_{f}=\right.$ $28.4^{\circ}$ ), then $f$, which characterizes the degree of inclination shallowing, would be about 0.42 to account for the observed 
inclination of the sediments $\left(I_{o}=12.9^{\circ}\right)$. This value of $f$ is within the range of values reported for some laboratory redeposition experiments, for example, varve sediments $(f=$ 0.4; King [1955]) and hematite-bearing river deposits $(f=$ 0.55; Tauxe and Kent [1984]). Although the possibility that the shallower inclination of the sedimentary $C$ component magnetization is due to a depositional or compaction-related inclination error cannot therefore be excluded, we found no evidence of anomalously shallow inclinations in results from similar but older and more deeply buried Carnian/Norian sedimentary rocks of the Newark basin which agreed well with expected Late Triassic inclinations [Witte and Kent, 1989].

Alternatively, the basalt mean direction reported by McIntosh et al. [1985] may not provide an accurate record of the Hettangian field. We note that the basalt mean direction falls between the $C$ component and the $B$ component directions from the extrusive zone strata, which together essentially define a great circle which includes the present-day field direction. This presents the possibility that the reported basalt magnetization may represent a resultant direction composed of a component similar to the sedimentary $C$ component magnetization contaminated by younger ( $B$ component and/or present-day field) magnetizations.

\section{Basalts}

We attempted to test this hypothesis by subjecting a suite of Watchung basalt samples from six sites in six separate cooling units to detailed progressive demagnetization. The NRM intensities of basalt samples varied between 1 and $10 \mathrm{~A} / \mathrm{m}$. Although both AF and thermal demagnetization techniques were employed, they yielded very similar demagnetograms (Figures $4 a$ and $4 b$ ). The average median destructive alternating field encountered during AF demagnetization experiments was only about $10 \mathrm{mT}$, even though the average median destructive temperature was relatively high $\left(415^{\circ} \mathrm{C}\right)$. We report primarily on the results of the AF demagnetization experiments for comparison to previous results.

McIntosh et al. [1985] sampled 18 sites in the basalts, however, we obtained a similar mean direction if calculated at the same AF treatment level of $20 \mathrm{mT}\left(006.4^{\circ} / 22.8^{\circ}, \alpha_{95}=\right.$ $15.8^{\circ}$ for $N=6$ sites), indicating that our sampling, although less extensive, was at least representative of the results of McIntosh et al. [1985]. Despite this apparent agreement there is considerable variability in the demagnetization behavior of the basalt samples.

Demagnetograms for samples from all three sites of the Orange Mountain Basalt typically indicate univectorial decay to the origin above $20 \mathrm{mT}$, after the removal of a spurious low coercivity magnetization (Figure 4d). Samples from near the base of the Preakness (site TRB) also displayed linear demagnetization trajectories above $20 \mathrm{mT}$, with northward and very shallow upward directions (tilt corrected mean $=011.8 \%$ $7.5^{\circ}, \alpha_{95}=5.8^{\circ}$; Figure $4 c$ ), similar to those reported from near the base of the Preakness by McIntosh et al. [1985] along I-280, and by Hozik [1988] in Little Falls, New Jersey. On the other hand, demagnetograms of samples from near the top of the Preakness (site TRA) are curvilinear with no distinct lincar trajectories isolated before complete demagnetization in either AF (up to $80 \mathrm{mT}$ ) or thermal (up to $580^{\circ} \mathrm{C}$ ) experiments (Figures $4 a$ and $4 b$ ). The NRM directions are steep, similar to the present-day field direction, and shallowed with increasing demagnetization treatment. Finally, samples from the Hook
Mountain site yielded unresolved multicomponent demagnetizations similar to those observed at the Preakness site TRA (Figure 4e).

For the magnetizations in four of the six sites we sampled which showed univectorial decay to the origin (TOA, TOB, TOC, and TRB), principal component analysis yields a tiltcorrected mean direction of $002.6^{\circ} / 18.3^{\circ}\left(\alpha_{95}=22.0^{\circ}\right)$ (Table 3). This is about $10^{\circ}$ shallower than the mean for 18 sites $\left(007.7^{\circ}, 28.4^{\circ}\right)$ reported by $M c I n t o s h$ et al. [1985] and closer to the mean direction of the $\mathrm{C}$ component $\left(006.2^{\circ} / 12.8^{\circ}\right)$, although the radius of $95 \%$ confidence is large due to the small number of acceptable sites in our analysis. In the remaining two basalt sites (TRA and THA), a characteristic component of magnetization could not be well isolated even after extensive demagnetization due to contamination by magnetizations with completely overlapping coercivity (and unblocking temperature) spectra.

\section{PALEOPOLES AND Discussion}

The redbeds of the Newark basin extrusive zone carry two important ancient magnetizations of normal polarity, the B and $\mathrm{C}$ components, which can be resolved by thermal demagnetization. The intermediate unblocking temperature (B component) overprint in the extrusive zone, which was well resolved in only 4 of the 13 outcrop sites due to either its absence or near colinearity with the $C$ component in many samples, yields a paleopole position at $68.7^{\circ} \mathrm{N}, 94.3^{\circ} \mathrm{E}\left(\mathrm{A}_{95}=\right.$ $9.1^{\circ}$ for $N=4$ site-mean VGPs in geographic coordinates). The corrected mean colatitude (using the correction method of Cox and Gordon [1984]) from the azimuthally unoriented ACE cores is $72.4^{\circ}$, with a standard deviation of $6.1^{\circ}$, for 23 independently oriented samples. Combining the paleopole datum and colatitude datum [Gordon and Cox, 1980], we obtain a best fit pole of $68.0^{\circ} \mathrm{N}, 94.6^{\circ} \mathrm{E}$ and a $95 \%$ confidence ellipse with axes of $7.8^{\circ}$ and $9.2^{\circ}$ (minor axis azimuth of $351^{\circ}$ ). This best fit and preferred $B$ component pole is not significantly different (great circle distance $=4^{\circ} \pm 10^{\circ}$ at the $95 \%$ confidence level) from the well-determined overprint paleopole isolated in the older Camian/Norian strata of the Newark basin $\left(72.7^{\circ} \mathrm{N}\right.$, $89.8^{\circ} \mathrm{E}, \mathrm{A}_{95}=3.4^{\circ}, N=22$; Witte and Kent [1989]) (Table 4, Figure 5).

As noted in the introduction, recent ${ }^{40} \mathrm{Ar} /{ }^{39} \mathrm{Ar}$ work indicates that many of the Newark igneous intrusions whose primary crystallization occurred at $\sim 200 \mathrm{Ma}$, suffered a hydrothermal event at $-175 \mathrm{Ma}$ which reset their radiometric ages [Sutter, 1988]. We previously noted the close similarity between the paleomagnetic pole corresponding to the overprint magnetization in the Camian/Norian Newark sediments and the N2 pole from the Newark igneous intusion (when both are considered either with or without tilt correction) and suggested this could be attributed to a common remagnetization event [Witte and Kent, 1989]. Although the evidence is indirect, we infer that the sediments of the Newark extrusive zone were also overprinted during the same hydrothermal event at $-175 \mathrm{Ma}$, which resulted in the overprinting of the older Newark sediments as well as the remagnetization and age resetting of the Newark igneous intrusions after tectonic tilting.

We interpret the high unblocking temperature $\mathbf{C}$ component as the characteristic magnetization of the extrusive zone sedimentary rocks; however, the mean direction after tilt correction $\left(006.3^{\circ} / 12.9^{\circ}, \alpha_{95}=6.0^{\circ}\right)$ is significantly shallower than the tilt-corrected mean direction reported by 


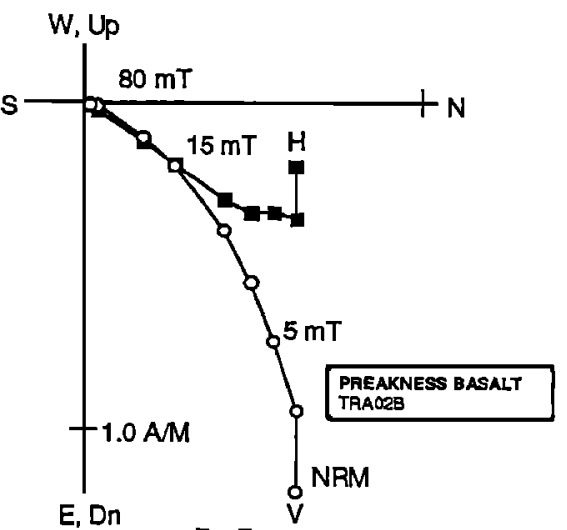

[a]

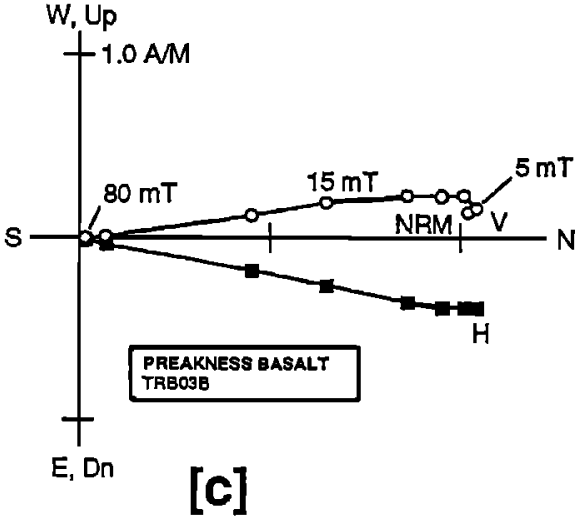

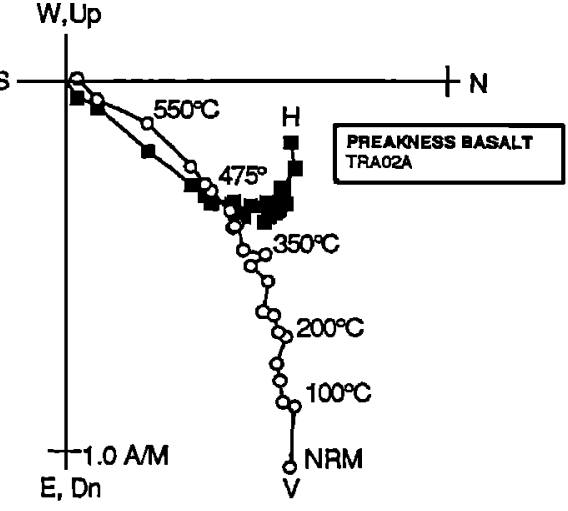

[b]

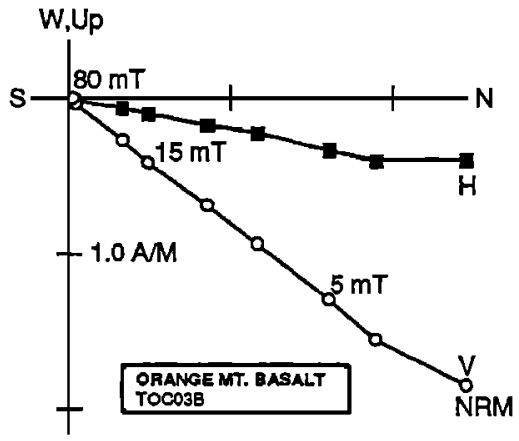

E, Dn
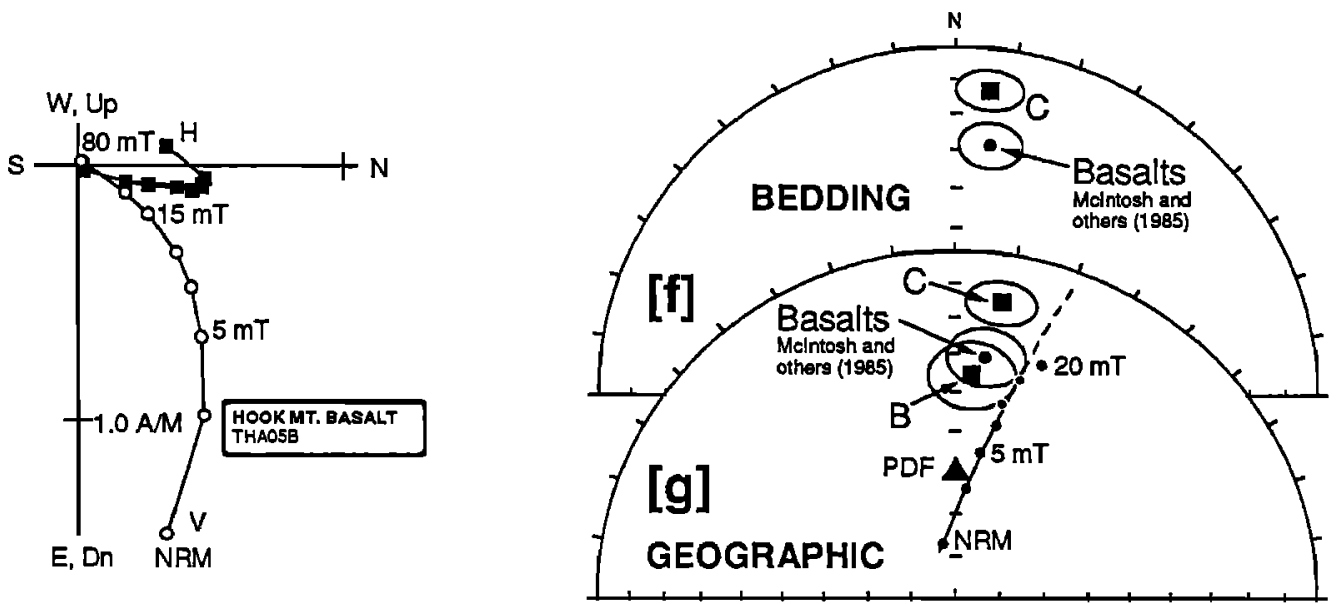

[e]

Fig. 4 Paleomagnetic results from Newark extrusive zone basalts. Zijderveld [1967] demagnetograms showing progressive demagnetization of samples from the $(a, b$, and $c)$ Preakness, (d) Orange Mountain, and (e) Hook Mountain Basalts. Figures $4 a$ and $4 b$ show the AF and thermal demagnetizations of companion specimens cut from the same core. Equal area stereographic projections of magnetization directions obtained from the basalts and sedimentary rocks of the extrusive zone in the $(f)$ bedding and $(g)$ geographic frames of reference. The Hettangian extrusive zone mean $C$ component directions $(N=$ 11 ) and the mean $B$ component directions $(N=4)$ are shown by squares with their $\alpha_{95}$ ellipses. Circle with $\alpha_{95}$ ellipse in Figure $4 f$ denotes the mean direction reported by McIntosh et al. [1985] from their study of 18 sites in the extrusive zone basalts, and in Figure $4 g$ the basalt mean direction in the geographic frame of reference estimated by removing the tilt correction from the McIntosh et al. [1985] tilt-corrected site mean directions using bedding attitudes estimated from Lyttle and Epstein's [1987] geologic map of the area and from our ow'n measurements. Included in Figure $4 g$ are the directions from progressive AF demagnetization of the Hook Mountain Basalt sample in Figure $4 e$ (small solid circles) with the best fit great circle shown. 
TABLE 3. Site Means for basalts with univectorial demagnetizations

\begin{tabular}{lccccccc}
\hline Site & $\mathbf{n}$ & $\mathbf{k}$ & $\alpha_{95}$ & GDec & GInc & BDec & BInc \\
\hline TOA & $3 / 5$ & 667 & 4.8 & 003.8 & 37.1 & 354.6 & 30. \\
TOB & $4 / 6$ & 241 & 5.9 & 003.2 & 27.8 & 357.0 & 21.5 \\
TOC & $4 / 6$ & 180 & 6.9 & 014.4 & 31.3 & 006.1 & 27.5 \\
TRB & $4 / 6$ & 255 & 5.8 & 010.3 & -3.9 & 011.8 & -7.5 \\
Geo & $4 / 6$ & 18 & 22.0 & 008.0 & 23.4 & - & - \\
Bed & $4 / 6$ & 18 & 22.0 & - & - & 002.6 & 18.3 \\
\multicolumn{7}{c}{ Column headings as in Table 2. }
\end{tabular}

McIntosh et al. [1985] from the interbedded and therefore coeval Watchung basalts $\left(007.7^{\circ} / 28.4^{\circ}, \alpha_{95}=6.2^{\circ}\right)$. A likely explanation for this discrepancy emerged from a detailed progressive AF and thermal demagnetization analysis of representative Watchung basalt samples which revealed more complicated magnetizations than previously suspected in onethird of the sampling sites. The blanket AF demagnetizing field used in previous studies of the basalts [e.g., McIntosh et al., 1985] has typically been $20 \mathrm{mT}$ or less; this treatment would be sufficient to isolate a characteristic magnetization in some but not all of the basalts we examined. The inclusion of data from samples demagnetized to only $20 \mathrm{mT}$, but for which we observed curvilinear trajectories upon more complete demagnetization, would tend to bias the overall mean direction away from the characteristic direction and toward the steeper contaminating secondary direction(s), the present-day field and/or the -175 Ma (Middle Jurassic) overprint component (Figure $4 f$ ).

Moreover, the Orange Mountain, Preakness, and Hook Mountain basalts collectively consist of only perhaps 11 cooling units [Fedosh and Smoot, 1988]. Even if primary magnetizations could be isolated consistently from the basalts, it is not clear to what extent paleosecular variation could be averaged with such a small number of potentially available spot readings of the ancient field [Prévot and McWilliams, 1989]. In contrast, most of the estimated 670,000-year duration of the Newark extrusive zone [Olsen and Fedosh, 1988; Olsen et al., 1989] is represented by the sedimentary interbeds, over which we have good sampling coverage. This lends further support to our contention that the sedimentary C component magnetization provides a better estimate than the available basalt data of the time-averaged Hettangian geomagnetic field for the Newark basin and presumably stable North America.
The $11 \mathrm{C}$ component site VGPs from Newark extrusive zone sedimentary rocks in outcrop yield a pole position before tilt correction at $56.1^{\circ} \mathrm{N}, 90.0^{\circ} \mathrm{E}, \mathrm{A}_{95}=5.7^{\circ}$, and a pole at $55.3^{\circ} \mathrm{N}$, $94.5^{\circ} \mathrm{E}, \mathrm{A}_{95}=5.4^{\circ}$ after tilt correction (Table 4, Figure 5). The two poles differ by only $2.7^{\circ}$, and although the correct frame of reference is not explicitly tested in extrusive zone sediments, we prefer the tilt-corrected pole because of the positive fold test from the Passaic Formation sediments directly below the extrusive zone [Witte et al., 1989]. The mean colatitude [Cox and Gordon, 1984] determined from the ACE inclination-only data after tilt correction is $79.8^{\circ}$, with a standard deviation of $8.4^{\circ}$ for 19 independently oriented samples. Combining the tilt-corrected paleopole datum and colatitude datum [Gordon and Cox, 1980], we obtain a best fit $\mathrm{C}$ component pole at $55.5^{\circ} \mathrm{N}$, $94.6^{\circ} \mathrm{E}\left(95 \%\right.$ confidence ellipse with axes of $5.2^{\circ}$ and $5.4^{\circ}$, minor axis azimuth of $351^{\circ}$ ) very similar to the outcrop paleopole position.

The best fit and preferred pole is significantly different from the N1 pole $\left(63.0^{\circ} \mathrm{N}, 83.2^{\circ} \mathrm{E}, \mathrm{A}_{95}=2.3^{\circ} ;\right.$ Smith and Noltimier [1979]) which is largely based on earlier paleomagnetic results from the Watchung basalt flows and the coeval and lithologically similar flows of the Hartford basin. Based on our demagnetization experiments on the Watchung basalts, we suggest that the N1 paleopole is also probably biased toward higher latitudes by secondary components of magnetization whose presence would be difficult to systematically detect and remove with AF cleaning only to about 15 or $20 \mathrm{mT}$, as has been commonly employed. The inference that the reported magnetization directions of $\mathrm{N} 1$ rocks are partially contaminated by unremoved components of Middle Jurassic to Recent age is supported by our conclusion that contemporaneous (and probably comagmatic) Newark trend igneous intrusions, which contribute to $\mathrm{N} 2$, are often completely remagnetized.

\section{RELEVANCE TO APPARENT POLAR WANDER OFNORTH AMERTCA}

Gordon et al. [1984] proposed that APW for North America from the Late Carboniferous to Cretaceous can be modeled as two small-circle tracks, each representing $\sim 100$ m.y., separated by a sharp cusp located at about $60^{\circ} \mathrm{N}, 60^{\circ} \mathrm{E}$ and dated at roughly the Triassic/Jurassic boundary (Figure 5). The data judged to be reliable and which bracket the cusp or abrupt change in the direction of APW according to this and the subsequent analysis by May and Butler [1986] are from the Carnian-Norian Chinle Formation (off and on the Colorado

TABLE 4. Paleopoles from Hettangian extrusive zone sedimentary rocks

\begin{tabular}{|c|c|c|c|c|c|c|c|c|c|}
\hline & & & Geof & phic & & & Tilt: & rected & \\
\hline & $\mathbf{N}$ & Lat & Lon & $\mathbf{K}$ & $\mathrm{A}_{95}$ & Lat & Lon & $\mathbf{K}$ & $\overline{A 95}$ \\
\hline & & & & $C C$ & onent & & & & \\
\hline Outcrop only & 11 & $56.1^{\circ}$ & $90.0^{\circ}$ & 64 & $5.7^{\circ}$ & $55.3^{\circ}$ & $94.5^{\circ}$ & 72 & $5.4^{\circ}$ \\
\hline $\begin{array}{l}\text { Outcrop with } \\
\text { borehole mean }\end{array}$ & 12 & - & - & - & - & $55.5^{\circ}$ & $94.6^{\circ}$ & $D, d m=$ & $\left.2^{\circ}, 5.4^{\circ}\right)$ \\
\hline & & & & $B C$ & onent & & & & \\
\hline Outcrop only & 4 & $68.7^{\circ}$ & $94.3^{\circ}$ & 103 & $9.1^{\circ}$ & $63.3^{\circ}$ & $108.3^{\circ}$ & 119 & $8.5^{\circ}$ \\
\hline $\begin{array}{l}\text { Outcrop with } \\
\text { borehole mean }\end{array}$ & 5 & $68.0^{\circ}$ & $94.6^{\circ}($ & $D, d n=$ & $\left.8^{\circ}, 9.2^{\circ}\right)$ & - & - & - & - \\
\hline
\end{tabular}




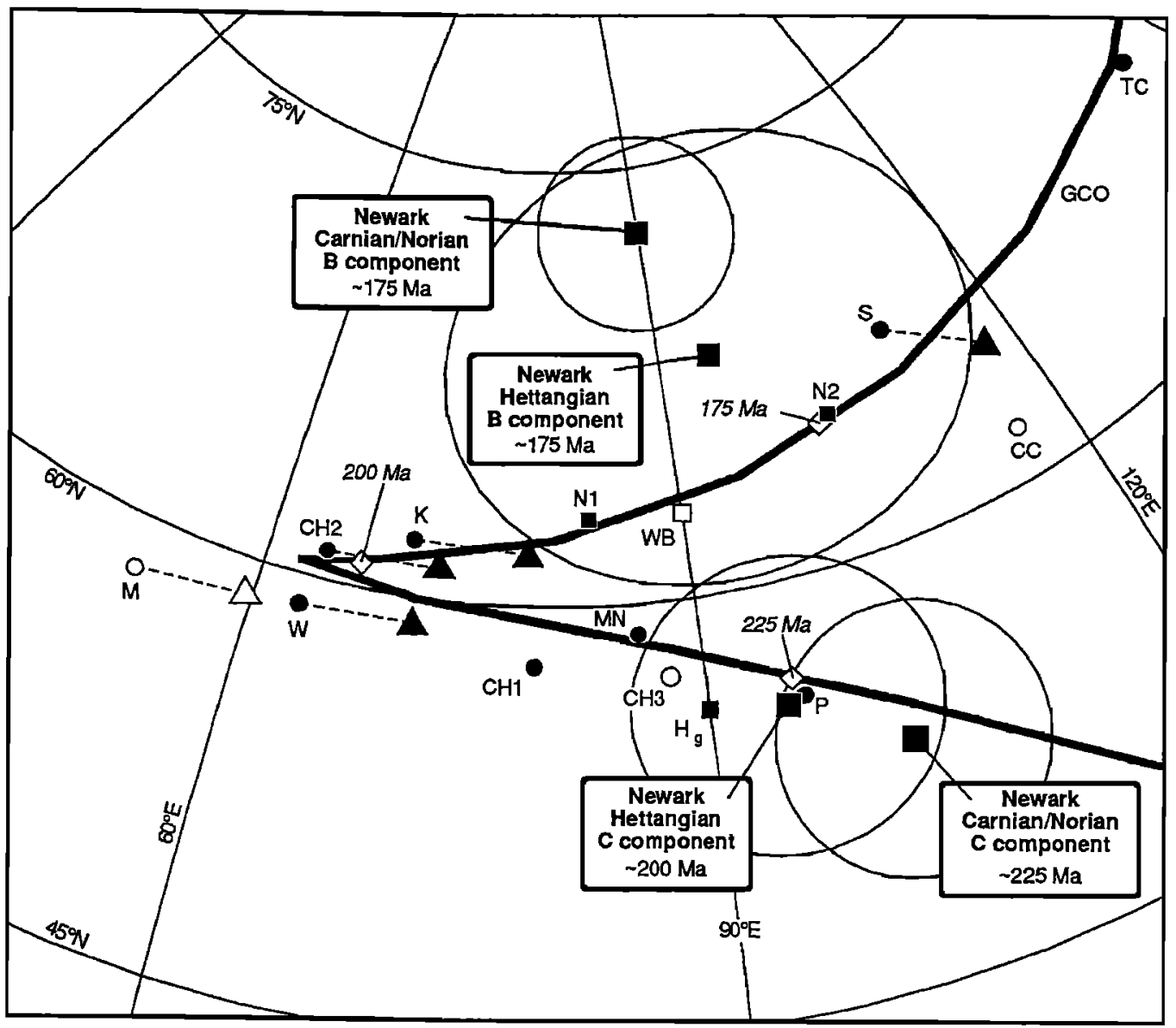

Fig. 5 Late Triassic through Middle Jurassic APW paths and paleomagnetic poles for North America. Solid circles are reference poles listed and used in the Gordon et al. [1984] APW (the heavy curve with $225 \mathrm{Ma}, 200 \mathrm{Ma}$, and $175 \mathrm{Ma}$ synthetic pole positions shown by open diamonds): P - Camian/Norian Popo Agie pole, CH1 - Late Triassic Chinle (Redonda Member) pole, MN - $215 \mathrm{Ma}$ Manicouagan impact structure pole, W - Sinemurian Wingate pole, CH2 - Late Triassic Chinle (Church Rock Member) pole, K - Pliensbachian Kayenta Formation pole, N1 - 195 Ma "Newark trend" igneous pole, N2 - 179 Ma "Newark trend" igneous pole, S - Late Callovian Summerville pole, TC - Middle Bajocian or Early Callovian Twin Creek pole. Also shown (open symbols) are more recent results: CH3 - Late Triassic Chinle Formation pole [Bazard and Butler, 1989], M - Sinemurian/Pliensbachian Moenave Formation pole [Erkstrand and Butler, 1989], WB Hettangian Watchung Basalt pole [McIntosh et al., 1985], and CC - $172 \mathrm{Ma}$ Corral Canyon pole [May et al., 1986]. Triangles indicate the location of the W, M, K, and $S$ poles after correction for $4^{\circ}$ of Colorado Plateau rotation. Large solid squares indicate pole positions (with their $\alpha_{95}$ confidence envelopes) from the Newark basin of the B component (no tilt correction) and $C$ component (tilt-corrected) from Hettangian extrusive zone sedimentary rocks (this paper) and from Camian/Norian sedimentary rocks [Witte and Kent, 1989]. $\mathrm{H}_{\mathrm{g}}$ indicates the pole position for the $\mathrm{C}$ component from Hettangian extrusive zone sedimentary rocks in geographic coordinates.

Plateau: Reeve and Helsley [1972] and Reeve [1975], respectively), the $215 \mathrm{Ma}$ Manicouagan structure [Robertson, 1967; Larochelle and Currie, 1967], the Sinemurian Wingate Formation [Reeve, 1975], the Pliensbachian Kayenta Formation [Steiner and Helsley, 1974], and the so-called Newark trend Igneous Groups I and II (N1 and N2 poles) of Smith and Noltimier [1979].

The Newark N1 pole is out of spatiotemporal sequence in these paleomagnetic Euler pole models of APW: the extrusive zone of the Newark and Hartford basins, including the basalts that comprise the $\mathrm{N} 1$ pole, is biostratigraphically confined to the Hettangian, yet the N1 pole plots on the postcusp portion of the APW path, considerably to the east of Colorado Plateau poles from the Sinemurian Wingate Formation, the Pliensbachian Kayenta Formation, as well as a recent result from the Sinemurian/Pliensbachian Moenave Formation [Erkstrand and Butler, 1989] which help to define the cusp
(Figure 5). This discrepancy can be resolved if, as argued above, the high unblocking temperature (C component) pole from the Newark extrusive zone sedimentary rocks is accepted as a reliable estimate of the Hettangian paleopole whereas the higher latitude $\mathrm{N} 1$ pole is regarded as contaminated by secondary magnetizations. This would place the Hettangian pole for North America on the precusp portion of the APW path, in a sequence consistent with biostratigraphic constraints which indicate that the Newark extrusive zone Iocks [Cornet and Olsen, 1985; Olsen et al., 1989] are somewhat older than the Wingate, Kayenta, and Moenave Formations [Imlay, 1980]. The general lack of Hettangian-age sedimentary rocks in western North America [Imlay, 1980] precludes a more direct comparison of paleopole data from North America to the Newark extrusive zone result.

An altemative interpretation, that the $C$ component of magnetization is postfolding and should be considered in the 
geographic frame of reference, results in a pole position that still plots on the precusp track of the APW path (Figure 5). However, because the age of magnetization would then necessarily be at least of post-Hettangian age, the corresponding pole position would be very much out of spatiotemporal sequence and create severe complications for Jurassic APW. Thus we consider this alternative hypothesis unlikely.

The Manicouagan structure is regarded by Gordon et al. [1984] as Late Triassic, nominally older than the Hettangian extrusive zone rocks of the Newark basin, yet the pole position they calculated at $59^{\circ} \mathrm{N}, 86^{\circ} \mathrm{E}, \mathrm{A}_{95}=7^{\circ}$ is closer to the cusp, thus suggesting a younger age relative to the Newark Hettangian pole. This disagreement may be more apparent than real because (1) the difference $\left(6^{\circ} \pm 9^{\circ}\right.$ at the $95 \%$ confidence level) between the Manicouagan and Newark Hettangian poles is not statistically significant; (2) the K-Ar age for the Manicouagan of $215 \pm 4 \mathrm{Ma}$ (Wolfe [1971] recalculated for new decay and abundance constants by Gordon et al. [1984]) encompasses within its uncertainty the Hettangian Age according to some recent geologic time scales [e.g., Harland et al., 1982] although not according to others (e.g., the DNAG time scale, Palmer [1983]); (3) the whole-rock and mineral K-Ar age data on the Manicouagan impact structure in any case may be complicated by the possibility of excess argon inherited from the shocked and melted Precambrian and Paleozoic country rock [Wolfe, 1971; Olsen et al., 1987).

A more complex disparity exists between poles from the Chinle Formation and the Newark basin. Although there is considerable uncertainty in the age and definition of the Chinle Formation [e.g., Pipiringos and O'Sullivan, 1978; Lucas and Hunt, 1989], the bulk of what has been called Chinle Formation is usually considered to be of Camian and/or Norian age. Chinle paleopoles used in recent APW path syntheses fall to the west of our Camian/Norian pole and even our Hettangian pole from the Newark basin (Figure 5). Correction for Colorado Plateau rotation ( $4^{\circ}$ according to Bryan and Gordon [1986]; or perhaps $10^{\circ}$ according to Steiner [1986]) might reconcile the $\mathrm{CH} 2$ pole [Reeve, 1975] from the Church Rock Member of the Chinle Formation on the Colorado Plateau with the $\mathrm{CH} 1$ pole [Reeve and Helsley, 1972] from the Redonda Member of the Chinle from off the Colorado Plateau; however, both of them would remain incompatible with our Camian/Norian results from the Newark. Preliminary results from the Chinle (or one of its equivalents) of Camian/Norian age and sampled off the Colorado Plateau in New Mexico [Bazard and Butler, 1989] extend the longitudinal range of Chinle paleopoles to $57.4^{\circ} \mathrm{N}, 87.8^{\circ} \mathrm{E}$ (Figure 5). These disparate results from the Chinle would seem to require larger tectonic rotations of the Colorado Plateau than have been previously suggested, a syndepositionally magnetized Chinle of variable age (from Late Triassic through earliest Jurassic), and/or a Camian/Norian Chinle variably contaminated by a cusplike field. Our Newark Hettangian extrusive zone sedimentary pole, on the other hand, does not resemble cusp or other known younger paleomagnetic poles for North America and its close proximity to the Newark Carnian/Norian paleopole would argue against rapid APW during the Carnian/Norian.

Though our Newark Hettangian pole lies close to the precusp small circle track of Gordon et al. [1984], it would nevertheless require substantial changes in the rates of APW in the Late Triassic and Early Jurassic. The Newark Hettangian pole is only about $5^{\circ}$ more westerly (and in fact not significantly different) from the Newark Camian/Norian pole (Figure 5), implying only something of the order of $0.2 \%$ m.y. $\left(4.5^{\circ} \pm 7.2^{\circ}\right.$ from $-225 \mathrm{Ma}$, the numerical age of the Camian/Norian boundary according to Palmer [1983], until $\sim 201 \mathrm{Ma}$, the age of the Newark extrusive zone according to Sutter [1988]) of APW over most of the Late Triassic (unless rapid back and forth APW during the Late Triassic is eventually shown to be responsible for the scatter in the Chinle poles). During the Early Jurassic the relative positions of the Hettangian (Newark extrusive zone) paleopole and the Sinemurian to Pliensbachian cusp (Wingate, Kayenta, and Moenave) paleopoles indicate a much more rapid APW rate of up to $4.6^{\circ} / \mathrm{m} . \mathrm{y}$. $\left(23.1^{\circ} \pm 7.0^{\circ}\right.$ during the $\sim 5 \mathrm{~m} . \mathrm{y}$. interval between the middle of the Hettangian to the middle of the Sinemurian according to Palmer [1983]). This rapid rate is reduced somewhat (to about $3.8^{\circ} / \mathrm{m} . y ., 19.2^{\circ} \pm 7.0^{\circ}$ in $\sim 5$ m.y.) if a correction is made for the $4^{\circ}$ of post-Triassic clockwise rotation of the Colorado Plateau (of course, larger amounts of Colorado Plateau rotation, e.g., Steiner [1986], would further decrease this rate). It should be emphasized that these estimates of a rapid rate of APW in the Early Jurassic depend heavily on the relative assigned ages of the Newark Supergroup and the sedimentary formations of the American southwest, in the context of the geologic time scale used (compare the Late Triassic of Palmer [1983] and Webb [1981]). On the other hand, the conclusion that APW was very slow in the Late Triassic is more certain because the time-stratigraphic framework internal to the Newark Supergroup is relatively well known [Cornet and Olsen, 1985].

In summary, our reinterpretation of key Late Triassic to Middle Jurassic North American reference poles based on results from the Newark basin suggests a more complicated pattem of APW than proposed by Gordon et al. [1984] or May and Butler [1986] in their paleomagnetic Euler pole analyses. For the precusp track, the age and position of the Hettangian Newark extrusive zone sedimentary paleopole relative to Late Triassic and younger Early Jurassic paleopoles indicate a large change in the rate of APW for North America, slow in the Late Triassic and fast in the Early Jurassic. For the postcusp portion, the high-latitude $\sim 175 \mathrm{Ma}$ (Middle Jurassic) pole position interpreted from the Newark sedimentary B component overprint magnetization and the N2 remagnetized directions, together with other recent indications of a highlatitude pole position for North America in the Middle Jurassic [Van Fossen and Kent, 1990], indicate a multisegmented Jurassic APW path substantially different from the simple onetrack models of Gordon et al. [1984] or May and Butler [1986]. As discussed recently by May and Butler [1986], substantial changes in the reference APW path, such as suggested here for the Jurassic, will have direct implications for the application of the North American APW path in Mesozoic terrane motion studies. Additional well-dated Jurassic paleomagnetic data will be necessary to document the character of APW for North America and to assess what potential remains for realistically describing APW in terms of revised paleomagnetic Euler pole small circles and cusps as the duration of tracks apparently diminishes to only a few tens of million years.

Acknowledgments. We thank P. E. Olsen for his comments concerning the geologic history of the Newark basin and his guidance to outcrop in the field area. R. G. Gordon kindly made available to us source code for combining paleomagnetic poles and paleo-colatitude estimates according to the method of Gordon and Cox [1980]. The manuscript was improved by the useful comments of R. W. Schlische, 
M. C. Van Fossen, P. E. Olsen and the joumal reviewers. This research was supported by the National Science Foundation, Earth Sciences Division (grants EAR86-18161 and EAR87-21142). Lamont-Doherty contribution \#4662.

\section{REFERENCES}

Anson, G. L., and K. P. Kodama, 1987, Compaction induced inclination shallowing of the post-depositional remanent magnetization in a synthetic sediment, Geophys. J. R. Astron. Soc., $88,673-692,1987$.

Bazard, D. R., and R. F. Butler, Paleomagnetism of the Chinle Formation, Arizona and New Mexico: Implications for Late Triassic Early Jurassic apparent polar wander (abstract), Eos, Trans. AGU, 70, 1068, 1989.

Bryan, P., and R. G. Gordon, Rotation of the Colorado Plateau: An analysis of paleomagnetic data, Tectonics, 5, 661 - 667, 1986.

Comet, B., and P. E. Olsen, A summary of the biostratigraphy of the Newark Supergroup of eastem North America with comments on Early Mesozoic provinciality, in Symposio Sobre Flores del Triasico Tardio su Fitografía y Paleoecologia, Memoria, edited by R. Weber, pp. 67 - 81, Instituto de Geologia Universidad Nacional Autonoma de Mexico, Mexico, 1985.

Cox, A., and R. G. Gordon, Paleolatitudes determined from paleomagnetic data from vertical cores, Rev. Geophys., 22, $47-72$, 1984.

Cummings, W. L., The role of sedimentary connate brines in the mineralization of the Watchung basalts, in Geology of the Central Newark Basin, Field Guide and Proceedings of the Fifth Annual Meeting of the Geological Association of New Jersey, edited by J. M. Husch and M. J. Hozik, pp. 135 - 147, Rider College, Lawrenceville, NJ, 1988.

Demarest, H. H., Error analysis for the determination of tectonic rotation from paleomagnetic data, J. Geophys. Res., 88(B5), 4321 4328, 1983.

Erkstrand, E. J., and R. F. Buller, Paleomagnetism of the Moenave Formation: Implications for the Mesozoic North American apparent polar wander path, Geology, 17, 245 - 248, 1989.

Fedosh, M. S., and J. P. Smoot, A cored stratigraphic section through the northem Newark basin, New Jersey, U.S. Geol. Surv. Bull., 1776, $19-24,1988$.

Fisher, R. A., Dispersion on a sphere, Proc. R. Soc. London Ser. A, 217, $295-305,1953$.

Gordon, R. G., and A. Cox, Calculating paleomagnetic poles for oceanic plates, Geophys. J. R. Astron. Soc., 63, 619-640, 1980.

Gordon, R. G., A. Cox, and S. O'Hare, Paleomagnetic Euler poles and the apparent polar wander and absolute motion of North America since the Carboniferous, Tectonics, 3, 499 - 537, 1984.

Harland, W. B., A. V. Cox, P. G. Llewellyn, C. A. G. Pickton, A. G. Smith, and R. Walters, A Geologic Time Scale, 92 pp., Cambridge University Press, New York, 1982.

Hozik, M. J., Progress in understanding the paleomagnetism of the Preakness Basalt, in Geology of the Central Newark Basin, Field Guide and Proceedings of the Fifth Annual Meeting of the Geological Association of New Jersey, edited by J. M. Husch and M. J. Hozik, pp. 107 - 133, Rider College, Lawrenceville, NJ, 1988.

Imlay, R. W., Jurassic paleobiogeography of the conterminous United States in its continental setting, U.S. Geol. Surv. Bull., 1062, 1980. Irving, E., Paleomagnetism and Its Application to Geological and Geophysical Problems, 399 pp., John Wiley, New York, 1964.

Irving E., and G. A. Irving. Apparent polar wander paths Carboniferous through Cenozoic and the assembly of Gondwana, Geophys. Surv., $5,141-188,1982$.

King, R. F., Remanent magnetism of artificially deposited sediments, Mon. Not. R. Astron. Soc. Geophys. Suppl., 7, 115 - 134, 1955.

Kirschvink, J. L., The least-squares line and plane and the analysis of paleomagnetic data, Geophys. J. R. Astron. Soc., 62, 699-718, 1980.

Kodama, K. P., Magnetic and gravity evidence for a subsurface connection between the Palisades sill and the Ladentown Basalts, Geol. Soc. Am. Bull., 94, 151 - 158, 1983.

Kodama, K. P., Comment on "Paleomagnetism of Early Jurassic rocks, Watchung Mountains, Newark basin: Evidence for complex rotations along the border fault," Geophys. Res. Lett., 14, 239 - 241, 1987.

Larochelle, A., and K. L. Currie, Paleomagnetic study of igneous rocks from the Manicouagan structure, Quebec, J. Geophys. Res., 72, 4163 - 4169, 1967.
Lucas, S. G., and A. P. Hunt, Revised Triassic stratigraphy in the Tucumcari basin, east - central New Mexico, in Dawn of the Age of Dinosaurs in the American Southwest, edited by S. G. Lucas and A. P. Hunt, pp. 150 - 170, New Mexico Museum of Natural History, Abuquerque, N.M., 1989.

Lyttle, P. T., and J. B. Epstein, Geologic map of the Newark $1^{\circ} \times 2^{\circ}$ quadrangle, New Jersey, Pennsylvania, and New York, U.S. Geol. Surv. Misc. Invest. Ser., Map I - 1715, U.S. Geol. Surv., Reston, Va., 1987.

May, S. R. and R. F. Butler, North American Jurassic apparent polar wander: Implications for plate motion, paleogeography, and Cordilleran tectonics, J. Geophys. Res., 91(B11), 11519-11544, 1986.

May, S. R., R. F. Butler, M. Shafiqullah, and P. E. Damon, Paleomagnetism of Jurassic volcanic rocks in the Patagonia Mountains, southeastem Arizona: Implications for the North American $170 \mathrm{Ma}$ reference pole, $J$. Geophys. Res., 91, 11,545 $11,555,1986$.

McFadden, P. L. and A. B. Reid, Analysis of paleomagnetic inclination data, Geophys. J. R. Astron. Soc., 69, $307-319,1982$.

McIntosh, W. C., R. B. Hargraves, and C. L. West, Paleomagnetism and oxide mineralogy of Upper Triassic to Lower Jurassic red beds and basalts in the Newark basin, Geol. Soc. Am. Bull., 96, 463. 480, 1985.

Olsen, P. E., The latest Triassic and Early Jurassic formations of the Newark basin (Eastern North America, Newark Supergroup): Stratigraphy, structure, and correlation, $N J$. Acad. Sci. Bull., 25, 25 $-51,1980$.

Olsen, P. E., and M. S., Fedosh, Duration of the early Mesozoic igneous episode in eastem North America determined by use of Milankovitch-type lake cycles (abstract), Geol. Soc. Am. Abstr. Programs, 20, 59, 1988.

Olsen, P. E., N. H. Shubin, and M. H. Anders, New Early Jurassic tetrapod assemblages constrain Triassic-Jurassic tetrapod extinction event, Science, 237, 1025 - 1029, 1987.

Olsen, P. E., R. W. Schlische, and P. J. W. Gore, Tectonic, Depositional, and Paleoecological History of the Early Mesozoic Rift Basins, Eastern North America, Field Trip Guide Book T351, AGU, Washington, D.C., 174 pp., 1989.

Opdyke, N. D., The paleomagnetism of the New Jersey Triassic: A field study of the inclination error in red sediments, J. Geophys. Res., 66, 1941 - 1949, 1961.

Palmer A. R., The decade of North American geology 1983 geologic timescale, Geology, 11, $503-504,1983$.

Philpotts, A. R., and A. Martello, Diabase feeder dikes for the Mesozoic basalts in southem New England, Am. J. Sci., 286, 105 126, 1986.

Pipiringos, G. N., and R. B. O'Sullivan, Principal unconfonnities in Triassic and Jurassic rocks, Western Interior United States-A preliminary survey, U.S. Geol. Surv. Prof. Pap., 1035-A, 29 pp., 1978.

Prévot, M., and M. McWilliams, Paleomagnetic correlation of Newark Supergroup volcanics, Geology, 17, 1007 - 1010, 1989.

Ratcliffe, N. M., Reinterpretation of the relationship of the the western extension of the Palisades Sill to the lava flows at Ladentown, New York, based on new core data, U.S. Geol. Surv. Bull., 1776, 113 - 135, 1988.

Reeve, S. C., Paleomagnetic studies of sedimentary rocks of Cambrian and Triassic age, Ph.D. dissertation, 426 Pp., Univ. of Texas al Dallas, 1975.

Reeve, S. C., and C. E. Helsley, Magnetic reversal sequence in the upper portion of the Chinle Formation, Montoya, New Mexico, Geol. Soc. Am. Bull., 83, 3795 - 3812, 1972.

Robertson, W. A., Manicouagan, P.Q., paleomagnetic results, Can.J. Earth Sci., 4, 641 - 649, 1967.

Schaller, W. T., The crystal cavities of the New Jersey zeolite region, U.S. Geol. Surv. Bull., 832, 1932.

Seidemann, D. E., W. D. Masterson, M. P. Dowling, and K. K. Turekian, K-Ar dates and ${ }^{40} \mathrm{Ar} /{ }^{39} \mathrm{Ar}$ age spectra for Mesozoic basalt flows of the Hartford basin, Connecticut, and the Newark basin, New Jersey, Geol. Soc. Am. Bull., 95, 594 - 598, 1984.

Smith, T. E., and H. C. Noltimier, Paleomagnetism of the Newark trend igneous rocks of the north central Appalachians and the opening of the central Atlantic Ocean, Am. J. Sci., 279, 778 - 807, 1979.

Steiner, M. B., Rotation of the Colorado Plateau, Tectonics, 5, 649 $660,1986$. 
Steiner, M. B., and C. E. Helsley, Magnetic polarity sequence of the Upper Triassic Kayenta Formation, Geology, 2, 191 - 194, 1974.

Sutter, J. F., Innovative approaches to the dating of igneous events in the early Mesozoic basins of the eastem United States, U.S. Geol. Surv. Bull., 1776, 194 - 200, 1988.

Tauxe, L., and D. V. Kent, Properties of a detrital remanence carried by haematite from study of modem river deposits and laboratory redeposition experiments, Geophys. J. R. Astron. Soc., 77, 543 $561,1984$.

Van Fossen, M. C., and D. V. Kent, High-latitude paleomagnetic poles from middle Jurassic plutons and moat volcanics in New England and the controversy regarding Jurassic apparent polar wander for North America, J. Geophys. Res., in press, 1990.

Van Fossen, M. C., J. J. Flynn, and R. D. Forsythe, Paleomagnetism of Early Jurassic rocks, Watchung Mountains, Newark basin: Evidence for complex rotations along the border fault, Geophys. Res. Lett., 13, 185 - 188, 1986.

Van Fossen, M. C., J. J. Flynn, and R. D. Forsythe, Reply to Kodama, Geophys. Res. Lett., 14, 242 - 244, 1987.

Webb, J. A., A radiometric time scale of the Triassic, J. Geol. Soc. Australia, 28, 107 - 121, 1981.

Witte, W. K., and D. V. Kent, A middle Camian to early Norian $(-225$
Ma) paleopole from sediments of the Newark basin, Pennsylvania, Geol. Soc. Am. Bull., 101, 1118 - 1126, 1989.

Witte, W. K., D. V. Kent, P. E. Olsen, Pre- and post-folding magnetizations of the Late Triassic Passaic Formation sediments in southeast Pennsylvania (abstract), Geol. Soc. Am. Abstr. Programs, 21(2), 76, 1989 .

Wolfe, S. H., Potassium - Argon ages of the Manicouagan Mushalagan Lakes structure, J. Geophys. Res., 76, 5424 - 5436, 1971.

Zijderveld, J. D. A., A.C. demagnetization of rocks: Analysis of results, in Methods in Paleomagnetism, edited by D. W. Collinson, M. K. Creer, and S. K. Runcom, pp. 254 - 286, Elsevier, New York, 1967.

D. V. Kent and W. K. Witte, Lamont-Doherty Geological Observatory, Palisades, NY 10964, USA.

(Received January 11, 1990;

revised June 4, 1990;

accepted June 4, 1990.) 